\title{
Onto-phenomenology of Spatial Memory in Adumbrations
}

\author{
Luís António Umbelino \\ Universidade de Coimbra \\ lumbelino@fl.uc.pt
}

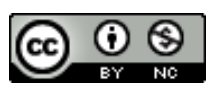

sciendo

Reception date: 15-11-2017

Acceptance date: 17-11-2017

\begin{abstract}
As we turn to the lived experience of memory, we are confronted with an eerie and enigmatic possibility: the possibility to remember what we ourselves never lived. How to explain phenomenologically this enigmatic but fundamental level of spatialized memory? I would like to come back to these issues in order to face yet another fundamental question: Does a phenomenology of spatialized memory require any ontophenomenological concretizations?
\end{abstract}

Keywords: Body, Memory, Space, Adumbrations

\section{Starting point}

As we turn to the lived experience of memory, we are confronted with an eerie and enigmatic possibility: the possibility to remember what we ourselves never lived.

We know that in histories of our past there are always bits of histories that others have told us about the same places, persons and events we can remember. In this sense, it is possible to say that I remember other people's memories as they mingle more or less consciously with my own, that my memories, as I recalled them and try to share them with others, are never just my own. But even more strange and uncanny is the circumstance where, in face of some places and objects, and under the pressure of an uncanny atmosphere of humanity transmitted by them, "I" seem to be able to remember, as present, the lived and emplaced presence of people I never knew. Merleau-Ponty 
demonstrates it a somewhat surprising way in Chapter IV of Phénoménologie de la perception:

Not only have I a physical world, not only do I live in the midst of earth, air and water, I have around me roads, plantations, villages, streets, churches, implements, a bell, a spoon, a pipe. Each of these objects is moulded to the human action which it serves. Each one spreads round it an atmosphere of humanity which may be determinate in a low degree, in the case of a few footmarks in the sand, or on the other hand highly determinate, if I go into every room from top to bottom of a house recently evacuated. (Merleau-Ponty, 1945: 399-400; 2002: 405).

Beneath a veil of anonymity, as if hanging on to cultural objects and places, the close (ghostly) presence of the other now gone is unequivocally felt, as if preserved by an Objective Spirit furtively operating in the ruins - as if objects and places could somehow preserve an uncanny memory of others and protect it from time's power of dispersion.

How to explain phenomenologically this enigmatic but fundamental level of spatialized memory? I have been working on these questions for some time now, and tried to offer some insights one them in several papers ${ }^{1}$. I would like to came back to these issues once again, this time in order to face yet another fundamental question: does a phenomenology of spatialized memory require any onto-phenomenological concretizations?

\section{Corporeal spatiality}

To understand in what way memory is never placeless, one must begin by suspending our common conception of space as we have inherited it from the implicit metaphysics of modern science; also we must place our approach on the side of the philosophical micro-tradition that prioritises space over time. In this context, an archaic level of approach requires a phenomenology of corporeal spatiality, as the one entailed by Merleau-Ponty in Phénoménologie de la perception. The body Merleau-Ponty is talking about in this book is, needless to

\footnotetext{
${ }^{1}$ See, for example, Umbelino (2016a; 2016b; 2015; 2013; 2011).
} 
say, the lived body and not just the objective body, "that conjunction of processes analysed in physiological logical treatises" (Merleau-Ponty, 1945: 401; 2002: 407). As is well known, Merleau-Ponty's original contribution regarding the body is his claim that "our" own bodies, the bodies we live as Leibkörper, are not merely subjective sites of corporeal sensation, nor merely personal, but also constitute a pre-reflexive, habitual, silent and general experience of being in the world (and having a world). My personal existence is the resumption of such a pre-personal perceptive body, which can be said to be

another subject beneath me, for whom a world exists before I am here, and who marks out my place in it. This captive or natural spirit is my body, not that momentary body which is the instrument of my personal choices and which fastens upon this or that world, but the system of anonymous 'functions' which draw every particular focus into a general project. (Merleau-Ponty, 1945: 294; 2002: 296)

This means that human subjectivity is embodied, and that to be is to be placed in a world that evades complete interiority. This world "is not an object such that I have in my possession the law of its making"; rather, it is "the natural setting of, and field for, all my thoughts and all my explicit perceptions" (1945: IX; 2002: XI-XII). In this sense, 'truth does not 'inhabit' only 'the inner man' or, more accurately, there is no inner man" (1945: IX; 2002: XII), no pure "for itself": we are of the world by means of the motility (or motor skills) of the habitual pre-personal body, and it is because of the enigmatic possibilities of the body's practical involvement that "we" begin to make praktognosic (1945: 164; 2002: 162) sense of a demanding world - a world that appears to the body as the promise of accomplishment of an original motor intentionality. Correspondingly, «my body must be apprehended not only in an experience which is instantaneous, peculiar to itself and complete in itself, but also in some general aspect and in the light of an impersonal being.» (1945: 98; 2002: 95).

It is at this level of "impersonal being" that "our" anonymous, pre-personal, or phenomenologically hidden body transmits an "already acquired spatiality" (1945: 293), a "spatiality of situation" that is phenomenologically different from the partes extra partes of a "spatiality of localization." This acquired spatiality is revealed by an enigmatic synchronized familiarity, composed by 
the habitual body's perceptive and motor dispositions and by practical interpellations or demands of lived space that constantly encourage certain significant bodily gestures, postures, movements and practical dynamic "choices". On this archaic level, to-be-in-the-world thus means to "have" a memory of the body's spatiality and spatial correspondences, that is to say, to "be" the memory of a praktognosic way of belonging as a body to the world.

\section{Phantoms}

Both the strength of such a practical correspondence and the way it puts in place something like a spatialized memory is traumatically demonstrated in the case of the phantom limb experience, where the depth of the time of the "I" is archaically secured by the way the pre-personal habitual body retains a presence, as still being present, of the being-in-the world in the scheme of selfhood - even against the certainties of reflective knowledge. As MerleauPonty points out

To have a phantom arm is to remain open to all the actions of which the arm alone is capable; it is to retain the practical field which one enjoyed before mutilation. The body is the vehicle of being in the world, and having a body is, for a living creature, to be intervolved in a definite environment, to identify oneself with certain projects and be continually committed to them (1945: 97; 2002: 94).

In the experience of the amputee, at the same time as the self is blocked by the certitude of the changes in the actual body, the habitual body continues to be a complete way of expansion and incorporation, thus maintaining intact, by ways of a kind of "spectral agency" (Trigg, 2012: 16) the bridge to the world destroyed by the amputation. Because of this temporal thickness sustained by the body, "a middle term between presence and absence", past and presence appears: a phantom of a member already dead is kept in the present as the anonymous body's spectral agency constitutes himself as refusing, or repressing (refoulement) of the past to slip into oblivion (Trigg, 2012: 16).

This is a key aspect of the problem: as a kind of motor intentionality, the body is a dynamic persistence that ensures the permanence of "our" world, even 
against the certainties of the thematic and personal thought. The body does so because it affords a retrieval of a previous unit established at the crossroads of the practical possibilities of motor intentionality and the mundane demands made to the body by the arrangements of the world; such a unit is strong enough to sustain, in spatial correspondences, the regular course of a kind of impersonal time that seems to "refuse" the amputation by not letting the amputee arm, and the space it responded to, be definitely lost in the past. In this sense, the presence, in the present, of an objectively absent limb is not a psychanalytic unconsciousness (Trigg, 2012: 16) at work, nor it is a kind of "representation" of the past: it is an "ambivalent presence" (Merleau-Ponty, 1945: 96; 2002: 93), of the past in the present, an almost presence felt now, re-enacted now, recovered now.

\section{Habit}

The body, as a spatial power, thus secures time, something Merleau-Ponty points out with his concept of "intentional arch" (Merleau-Ponty, 1945: 158; 2002: 157). But something more must be added to the analysis if we want to extend this possibility to the experience of phantom presences of others attached to objects.

To fully understand Merleau-Ponty's analysis at this point, we must understand his original analysis of the key concept of habit (of the habitual body). Here, the originality of Merleau-Ponty's approach consists in the fact that he views habit as entailing not only a "subjective side", made of bodily schemes and syntheses (already studied in detail by Husserl under the concept of habitus), but also an "objective side", which corresponds to how the body incorporates and redoubles a set of "habitual facts that go from objects to institutions and behaviours" (Bégout, 2005: 383). Habit is, according to Merleau-Ponty, an intersection of corporeal scheme with the body's dynamic capability - made up of expansion, dynamic enlargement or incorporation of objects, places, gestures, and behaviours ("offered to" a certain organization of the world already partially organised by the body itself) - to make familiar an intersubjective space. 
Therefore, habit is not just the corporal schematization produced in the "secret laboratory of passive synthesis" (Bégout, 2005: 384). Rather, it is a kind of practical and motor "implicit memory" (Fuchs, 2012: 69) that the body remembers as it re-enacts ancient correspondences and dis-positions learned by an ancient and anonymous calling for mundane incorporation. To "acquire the habit" of doing something is in some sense to have things in-habit the body by embodied annexation. This is why certain habits belong to certain places, objects or intersubjective circumstances. But what is truly decisive is that this way of inhabiting in fact comes in two modes, which correspond to a kind of mutual haunting: the body "haunts" objects and places since it is always expanding in their direction "by anticipation", and objects and places haunt the habitual body as a constant demand for practical correspondences (MerleauPonty, 1945: 161; 2002: 159). And when that practical hawser is given by the body, it becomes clear that habit is not just the expression of an inner schematization but also the expression, in the world, of the exteriorization - by incorporation and annexation - of the habitus.

In this sense, no "object" or place in the world is simply an object: all objects retain and protect traces of the human gesture of motor and behavioural incorporations. This is why we can literally say, with Merleau-Ponty, that "in the cultural object I feel the close presence of others beneath a veil of anonymity" (Merleau-Ponty, 1945: 400; 2002: 405); if in a "house recently evacuated" we encounter objects that exhale an atmosphere of humanity is because, so to speak, the objective side of the habitus remains "coagulated in the things" (Bégout, 2005: 390). Something of the body's anonymity is therefore preserved in objects and projected in shared behaviour, easily recognisable (sometimes against the most basic convictions of the reflexive conscience) by the general and impersonal being of the body as not merely "my" own.

We must conceive here a new idea of the objet: its materiality is always imbedded with spirit; that is to say, each object of the human world is a condensation of uses and corporal gestures, a projection of habitus that intersects the functionality of each object and distils in them - as a fundamental part of the objects' operatory schematizations - the presence in absence of a relatively anonymous humanized existence. Such a presence is vibrant for the lived body, even if not for our reflective conscience, which in the present faces 
merely abandoned objects. The presence, in the present of the object, of past incorporations, behaviours and dynamic correspondences of the other's anonymous, general and pre-personal habitual incorporations is "known" in "my" pre-personal body as an atmosphere of otherness that is always already familiar to the eerie dynamic re-enactments, intermixtures and embodied dynamic exchanges of the anonymous and remembering body.

\section{Carnal memory in adumbrations}

But what sustains such an archaic bodily familiarity? What sustains an experience of memory rooted in a body crossed from side to side by the word and the things of the world as they demand to be said in "me" before I begin to think about them?

Let us lay down, in adumbrations, the thinkable elements of a conceivable answer.

First adumbration: at a phenomenological level, the dominant self-reference of a spatialized memory is the body (and not an overflying spirit); memory thus must confirm that the body we are doesn't see "himself" as eccentric in relation to the world but as being part of the flesh of the world. In other words, the deep topocronia unfolded by the body does not correspond to the discovery of plain objects in front of me, nor of ideas constructed by an interior intellectual power. To remember must be, originally, the unfolding of a tacit and demanding involvement that appears archaeologically in certain movements of the lived body, as they are always directed and completed in a humanized world. In other words, memory seems to deal with the fact that human bodies - that are subjects beneath the subject - are not only an integral part of human lives, but also of the history of objects themselves: as if a part of the general way of being of the body was to found, rediscover, retrieve from the shape of the objects a memory of bodily incorporations of the world. But if this is so, then memory must also be somehow the retrieval, the recovery of the fabric that such archaic and familiar encounter presupposes.

In this sense - second adumbration -, if the fidelity to the phenomena of memory takes us right to the root of things beneath constituted humanity, and if we thus find the fabric of a tacit and ancient familiarity, we must also 
understand that such a fabric is not created by the subject, but surpasses him. If, in an abandon house, we experience the way objects spread round it an atmosphere of humanity, even if no one is there, it is surely because the body "knows more about the world then we do, about its motives and about the means required to make its synthesis" (Merleau-Ponty, 1945: 276; 2002: 277); but it also because such a carnal way of belonging of the body allows the communication with something more than its flesh. In that eerie encounter, both "my" body and the things of the world fully assumed in their materiality have an inherent meaning that is not just the one conveyed to them by interpretation, but the one inscribed in them by an ancient Being of involvement that universally represses, in place, the time of the mutual and chiasmatic involvement.

This is why - third adumbration - memory, when taken from the side of body and space, does not deal (not only at least) with meanings produced by a subject; legitimate memories are typically revealed memories of an ancient familiarity: the familiarity-let us say it in Merleau-Ponty's terms - of the "flesh of the world" the "flesh of the body" is made of. To remember, for the anonymous body we are, is then also to dynamically recover in each moment (that is to say: in each uncanny experience of the absent presence of others in manipulated objects and places) an access to the filigree of the selfunconcealment of the world.

Fourth adumbration: such filigree can be translated in terms of an ontological principle of involvement, connection and cohesion. It is to be understood as a "prototype of Being": a Being that cannot be understood as something formed from a background of nothingness, nor as some kind of bare and complete presence in the present, but as a Being of dimensionality and verticality, of visibility and invisibility, of presence and absence - or better yet: as Nichturpräsentierbar of the Urpräsentiert (Merleau-Ponty, 1964: 281). What comes closer to the meaning of such a Being - present everywhere as absence of its totality of involvement, and thus promising to secure and revel to the embodied being in the world more than his life, more than he thematically knows, more then he thinks he can remember - is the concept of ghost: being presence in absence.

If we belong by our carnal body - as if by imbriquement, by chiasmatic intertwining - to that fabric made of a reversible carnal intersection between 
the visible and the invisible it contains, so to "true memory" must be somehow made of the same fabric of belonging and carnal intersections. Consequently fifth adumbration - the Being that sustains that intertwining must sustain time by giving it space. In other words, space (understood as the dimension that constitutes itself around bodies and things; not as extension but as the dimension that grounds the relationships between embodied human beings and between them and the things of the world, the dimension where an archaic pact of mutual involvement is being constantly negotiated) must be the primordial dimension of Being.

\section{Bibliography}

Begout, B. (2005). La découverte du quotidien. Paris: Allia.

FuCHS, T. (2012). "Body memory and the Unconscious". In: D. Lohmar and J. Brudziňska (eds.). Founding Psychoanalysis Phenomenologically. Phaenomenologica 199. Dordrecht et al: Springer, 69-82.

Merleau-Ponty, M. (2002). Phenomenology of Perception. Eng. Trans: C. Smith. London \& New York: Routledge.

- (1945). Phénoménologie de la perception. Paris: Gallimard.

- (1964). Le visible et l'invisible. Paris: Gallimard.

TrigG, D. (2012). The Memory of Place. Phenomenology of the Uncanny. Athens: Ohio University Press.

UMBelino, L. A. (2016a). "Memory, Space, Oblivion". In: Scott Davidson, Marc-Antoine Vallée (eds.). Hermeneutics and Phenomenology in Paul Ricoeur. XXX: Springer, 115-122.

- (2016b). "On the Ricoeurian Projet of a Hermeneutics of Space”. In: Andrzej Wiercinski (ed.). Hermeneutics - Ethics - Education. Zurich: Lit Verlag, 199-206.

- (2015). "Memory of the Body, Temptation of Space". The European Legacy 20 (8): 844-851.

— (2013). "L'étoffe spatiale de la mémoire. Lectures de M. Merleau-Ponty et P. Ricœur". Studia Phaenomenologica 13: 325-334.

- (2011). "Herméneutique, architecture et humanisation de l'espace". Revue d'histoire et de philosophie religieuses 91 (1): 67-82. 
LUÍS ANTÓNIO UMBELINO is Assistant Professor at the Faculty of Arts of the University of Coimbra. He is member of the research unit $\mathrm{CECH}$ (Centro de Estudos Clássicos e Humanísticos - Portugal) and of the research project "Fenomenología del cuerpo y análisis del dolor" (FFI2013-43240-P - Spain); and director of Revista Filosófica de Coimbra. He publishes regularly, both in Portugal and abroad, on French reflexive tradition, contemporary phenomenology, and on philosophical hermeneutics. He has authored Somatologia Subjectiva. Apercepção de si e Corpo em Maine de Biran (2010), and has edited Hermeneutic Rationality. La rationalité herméneutique (2012) (with A. Wiercinski, and M. Silva), and Memória do Corpo, Tentação do Espaço (2015) (with N. Vieira). 